\title{
Identifikasi mineral kalsit di kawasan sungai desa Sumbermiri kecamatan Lengkong kabupaten Nganjuk dengan metode geomagnet
}

\author{
Prita Putri Dianti, Sutrisno*, Burhan Indriawan \\ Universitas Negeri Malang, Jl. Semarang No. 5 Malang, Jawa Timur, Indonesia \\ *Penulis korespondensi, Surel: sutrisno.fmipa@um.ac.id
}

Paper received: 01-08-2021; revised: 15-08-2021; accepted: 31-08-2021

\begin{abstract}
This research aims to identify the mineral rocks that are found in the river village districts of Sumbermiri village, Lengkong district, Nganjuk regency. XRF tests have been conducted on a rock an the result was 57 percent of the rocks is a calcite minerals. He method used is the geomagnetics, is by measurig the value of the total magnetic field in the area of research using the magnetometer. Data collection is done three times at each point, then retrieved the data with the smallest noise value to be processed. Corection calculation of the daily (diurnal) and IGRF corection. IGRF value of research location is 33281,4 , with the degree of inclination is 25,9993 and declination 8,1201. Then the data has be performed using a contour in the Surfer 10 and Magpick transform and see the contours of the surface magnetics field. Interpretation of results indicates calcite mineral content in the study area. Mag2DC modeling obtained using 2D contour transversely. On the first line, calcite rock has been indentified susceptibility of $-2,955--0,651$ with the misfit 747,79 . Second line has been susceptibility of $-0,897--0,249$ with the misfit 592,35 . Third line has been susceptibility of $0,509--0,005$ with the misfit 867,85 .
\end{abstract}

Keywords: Calcite Minerals; Geomagnetics; Rocks.

\begin{abstract}
Abstrak
Penelitian ini bertujuan untuk mengidentifikasi batuan mineral yang terdapat di kawasan sungai Desa Sumbermiri Kecamatan Lengkong Kabupaten Nganjuk. Telah dilakukan uji XRF pada batuan dan hasilnya adalah 57 persen batuan merupakan mineral kalsit. Metode yang digunakan adalah geomagnet, yaitu dengan melakukan pengukuran nilai medan magnet total di daerah penelitian dengan menggunakan magnetometer. Pengambilan data dilakukan tiga kali pada tiap titik, kemudian diambil data dengan noise terkecil untuk diolah. Dilakukan perhitungan koreksi harian (diurnal) dan koreksi IGRF secara manual. Nilai IGRF lokasi penelitian adalah sebesar 33281,4 dengan sudut inklinasi sebesar 25,9993 dan deklinasi 8,1201. Kemudian dilakukan olah kontur menggunakan Surfer 10 dan Magpick untuk melihat kontur medan magnet permukaan. Hasil interpretasi menunjukkan adanya kandungan mineral kalsit di daerah penelitian. Dengan menggunakan pemodelan Mag2DC didapatkan kontur 2D secara melintang. Pada lintasan pertama, batuan kalsit teridentifikasi memiliki suseptibilitas sebesar - 2,955 - -0,651 dengan misfit 747,79. Lintasan kedua memiliki suseptibilitas $-0,897--0,249$ dengan misfit 592,35. Lintasan ketiga memiliki suseptibilitas $-0,509--0,005$ dengan misfit 867,85 .
\end{abstract}

Kata kunci: Mineral Kalsit; Geomagnet; Batuan.

\section{Pendahuluan}

Indonesia memiliki potensi sumber daya mineral yang cukup besar (BSN,2002). Sumber daya mineral adalah semua bahan galian yang terdapat di bumi yang dapat dipakai untuk kebutuhan hidup manusia. Sumber daya mineral merupakan modal nasional yang perlu dikembangkan dan dimanfaatkan secara optimal untuk menunjang pembangunan. Namun, pemanfaatan sumber daya mineral tersebut harus memperhatikan konservasi dan upaya untuk kelestarian fungsi ekosistem (Perdana, 2013). 
Jenis mineral alam yang menyusun kerak bumi ini sudah sagat banyak sekali bahkan lebih dari 2.000 jumlahnya. Bila dilihat dari susunan kimianya daat dibagi menjadi sebelas golongan, yaitu: elemen elemen nativ; sulfida; halida; oksida dan hidroksida; karbonat; nitrat; tungsten dan molidan; phospat, arsenat dan vanadan; sulfat; borak; dan silikat (Graha, 1987)

Mineral terbentuk secara anorganik, mempunyai komposisi kimia pada batas-batas tertentu dan memiiki atom-atom yang tersusun secara teratur, mineral merupakan komponen batuan yang membentuk lapisan kerak bumi (Britannica, 2008). Mineral seperti magnet, grafit dan berbagai sulfida yang terbentuk secara aami pada konduktifitas tanah. Karakteristik ini dapat digunakan untuk menentukan lokasi zona mineral (McHattie, 1981). Potensi batuan dan mineral terdapat di hampir setiap daerah di Indonesia, seperti pulau Sumatera, Kepulauan Riau, Pulau Kalimantan, Pulau Jawa, Pulau Sulawesi, Nusa Tenggara, Maluku dan Papua (ESDM, 2006).

Mineral kalsit atau dalam bahasa laboratorium disebut sebagai kalsium karbonat dapat dimanfaatkan dalam berbagai bidang, antara lain: sebagai bahan pembuatan cat, kertas dan karet; menghambat korositas dan menambahan kekerasan pada baja; serta penyusun bahan pembuatan keramik dengan kualitas tinggi.

Di Desa Sumbermiri, Kecamatan Lengkong Kabupaten Nganjuk terdapat kawasan sungai yang memiliki dasar sungai berupa batuan. Telah dilakukan uji XRF pada batuan tersebut dan hasilnya adalah $57 \%$ kandungannya berupa kalsium (Ca). Kandungan lain dari batuan tersebut adalah $\mathrm{Fe}(21 \%), \mathrm{Si}(9 \%)$, Al (2,6\%), K (2\%) dan lainnya adalah unsur pengotor.

Metode geomagnet adalah salah satu metode dalam geofisika yan mampu mengidentifikasi jenis batuan bawah permukaan bumi berdasarkan nilai susetibilitas magnetiknya. Penggunaan metode geomagnet sendiri didasarkan pada fungsinya yaitu mendeteksi objek yang terkubur dalam tanah dan mengevaluasi kedalaman objek tanpa merusak permukaan lahan penelitian untuk mengetahui kedalaman batuan dari permukaan agar dapat memperkirakan eksplorasi dan pemanfaatan batuan.

Berdasarkan uraian diatas dilakukanlah penelitian "Identifikasi Mineral Kalsit di Kawasan Sungai Desa Sumbermiri Kecamatan Lengkong Kabupaten Nganjuk dengan Metode Geomagnet". Penelitian ini dilakukan untuk mengetahui jenis batuan yang terdapat pada kawasan tersebut.

Titik lokasi penelitian sendiri berada pada posisi geografis $7^{\circ} 29^{\prime} 35.2^{\prime \prime}$ LS dan $112^{\circ} 03^{\prime} 15.6^{\prime \prime}$ BT. Keadaan alam lokasi penelitian adalah berupa aliran sungai, dengan sebuah muara. Dasar sungai bukan berupa pasir seperti pada umumnya, namun berupa batuan yang tidak terpisah satu sama lain.

Metode geomagnet memakai konsep pemetaan data yang didasarkan pada tingkat magnetiasi yang berbeda pada suatu batuan atau daerah yang akan diteliti yang diinduksi oleh medan magnet bumi. ini terjadi sebagai akibat adanya perbedaan sifat kemagnetan suatu material. Kemampuan untuk termagnetisasi suatu batuan bergantung dari nilai suseptibilitas yang dimiliki oleh setiap batuan. Nilai inilah yang dianggap penting dalam pencarian benda anomali karena adanya sifat yang khas untuk setiap jenis mineral atau jenis logam. Semakin besar nilai suseptibilitas yang ditemukan, maka bisa disimpulkan bahwa jumlah kandungan magnetik pada daerah batuan tersebut semakin banyak. 


\section{Metode}

Penelitian dilakukan pada tanggal 29 Maret 2015 pada pukul $09.00-17.00$.

\subsection{Alat Penelitian}

Komponen utama dalam pencarian data dalam penelitian menggunakan metode Geomagnet adalah Magnetometer. Selain itu dibutuhkan pula beberapa alat lainnya untuk menunjang jalannya penelitian, diantaranya:

2.1.1.GPS, untuk mengetahui titik koordinat lokasi penelitian

2.1.2. Kompas, untuk menentukan arah utara. Karena salah satu sistem kerja Magnetometer yang penting adalah menghadapkan antena ke utara.

2.1.3.Jam, sebagai penunjuk waktu dilakukannya penelitian.

\subsubsection{Alat tulis}

\subsection{Pengambilan Data Lapangan}

Dalam proses pengambilan data dalam penelitian geomagnet ini diukur nilai medan magnetik yang berada di setiap titik. Pengukuran dilakukan pada 44 titik tersebar pada daerah penelitian seluas $4.780 \mathrm{~m}^{2}$. Langkah-langkah yang diperlukan dalam pengambilan data dengan menggunakan magneto meter adalah sebagai berikut:

Dalam proses pengambilan data dalam penelitian geomagnet ini diukur nilai medan magnetik yang berada di setiap titik. Langkah-langkah yang diper-lukan dalam pengambilan data dengan menggunakan magnetometer adalah sebagai berikut:

2.2.1. Merangkai alat magnetometer, yaitu dengan menyusun staff (tongkat pe-nyangga) dengan sensor, memasukkan console ke dalam backpack yang dipasang di badan, dan memasang semua kabel konektor.

2.2.2. Mengatur konfigurasi waktu pada GPS: hari, tanggal, jam dan menit saat pengambilan data.

2.2.3. Menentukan base station sebagai titik pusat pengukuran.

2.2.4. Pengukuran diawali di titik base station, kemudian di titik plot tersebar di lokasi. Satu jam sekali melakukan pengukuran kembali di base station sebelum melanjutkan pengukuran di titik plot. Pengukuran di base station bertujuan untuk mengambil data awal dan akhir pengukuran dalam kurun waktu tertentu.

2.2.5. Mencatat letak titik pengukuran (posisi) dengan menggunakan GPS dan juga waktu pengambilan data. Pengambilan data harus memperhatikan sumbersumber magnetik yang tidak diharapkan, seperti: rel kereta, tiang listrik, kabel listrik, dan sebagainya.

2.2.6. Melakukan pengukuran medan magnet total menggunakan magnetometer. Antena magnetometer harus menghadap utara. Pengukuran dilakukan 3 kali yang kemudian akan dipilih satu nilai medan magnet yang memiliki noise terkecil. 
2.2.7. Titik plot pengambilan data dilakukan di tepian sungai dan dengan jarak yang tidak teratur karena menyesuaikan medan pada lokasi.

2.2.8. Melakukan proses tersebut pada sebanyak 44 titik yang menyebar di lokasi penelitian. 9. Mentransfer data hasil pembacaan ke komputer untuk pemrosesan lebih lanjut.

\subsection{Pengolahan Data}

Data awal yang telah didapatkan kemudian dilakukan koreksi diurnal, koreksi IGRF, olah kontur menggunakan aplikasi surfer 10, upward dengan aplikasi Magpick dan yang terakhir melihat kontur bawah permukaan dengan aplikasi Mag2dc. Untuk pengolahan data awal yang didapatkan dari hasil pengukuran menggunakan magnetometer yang harus dilakukan adalah mempertimbangkan data dengan nilai noise terkecil. Setelah ditentukan nilai titik dengan noise terkecil, kemudian dicari koreksi diurnal harian dan nilai besaran koreksi normal (IGRF) untuk mendapatkan nilai medan magnet lokal yang diteliti. Setelah didapatkan kontur, diperlukan pengangkatan ke atas (upward continuation) untuk mereduksi atau menghilangkan efek magnetik lokal yang berasal dari berbagai sumber benda magnetik yang tersebar di permukaan topografi yang mengganggu nilai sebenarnya dalam survei. Dalam upward continuation dalam penelitian ini digunakan software Magpick. Untuk mendukung interpretasi data yang telah diolah, diperlukan slicing untuk memetakkan data secara vertikal (ke dalam tanah 2 dimensi). Data hasil upward yang dianggap sudah benar-benar terupward dengan benar, dibuka kembali menggunakan software Surfer10. Dalam tahap ini, data anomali lokal yang sudah terpisahkan dengan regional dislicing. Kemudian dari data yang keluar, akan ditentukan bagian garis melintang yang akan dislicing untuk diinterpretasikan menggunakan Mag2dc. Pemodelan dengan menggunakan software Mag2dc berfungsi untuk pemodelan secara vertikal ke dalam untuk memperkirakan struktur lapisan-lapisan tanah yang ada di bawah daerah penelitian. Hasil akhir pengolahan data dari Mag2dc adalah berupa kontur vertikal magnetik dengan interval kontur tertentu untuk memperkirakan struktur lapisanlapisan tanah yang ada di bawah daerah penelitian.

\section{Hasil dan Pembahasan}

\subsection{Kontur Topografi}

Peta kontur topografi adalah peta kontur yang menunjukkan gambaran mengenai medan yang telah diteliti berdasarkan ketinggian area. Kontur topografi dibuat berdasarkan data longitude, latitude dan elevasi lokasi penelitian. 


\section{Gambar 4.1 Peta Kontur Topografi}

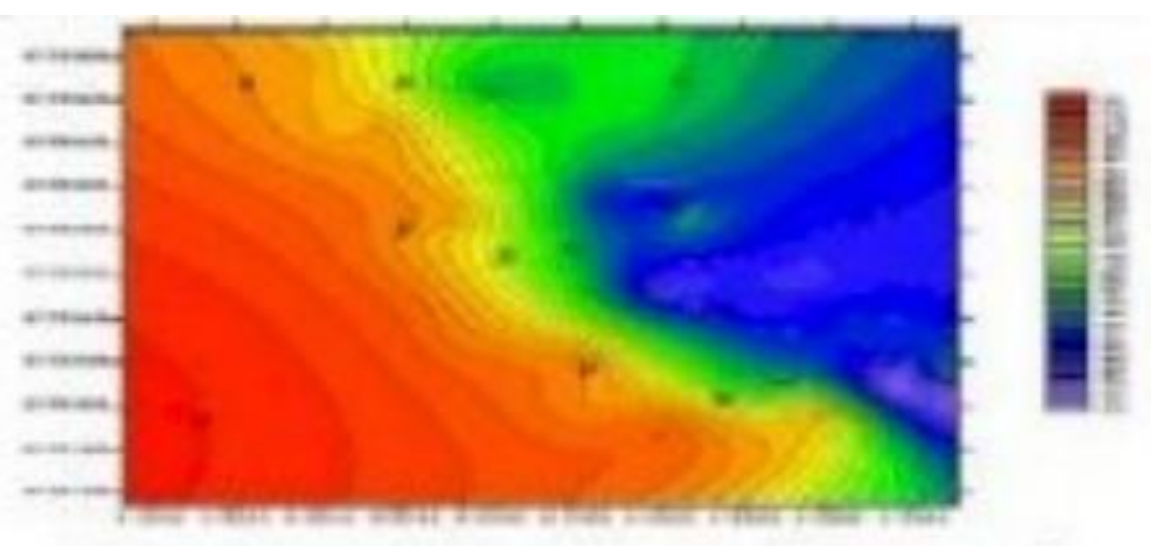

Kontur topografi di atas menggambarkan lokasi penelitian, bahwa pada lokasi tersebut memiliki ketinggian yang tidak merata dan cenderung semakin rendah ke bagian timur, yaitu daerah permukaan sungai sebagai lokasi penelitian. Berdasarkan skala dapat diketahui bahwa lokasi penelitian berada antara 122 meter sampai dengan 174 meter diatas permukaan laut.

\subsection{Medan Magnet Total}

Pembuatan peta kontur anomali magnetik didasarkan pada data magnetik yang diperoleh di awal yaitu berupa latitude, longitude dan medan magnet total awal (belum melalui proses koreksi apapun).

Gambar 4.2 Kontur Medan Magnet Total Tanda (+) yang tersebar pada gambar menyatakan titik pengambilan data. Titik pengambilan data tersebut tidak teratur, karena menyesuaikan medan pengambian data yang berupa sungai dan genangan airnya, dan hutan hutan.

Kontur anomali magnetik total merupakan gabungan antara anomali lokal dengan anomali regional dari target penyelidikan. Selanjutnya anomali regional yang tidak berhubungan dengan anomali target survei yang kemudian dihilangkan.

Kemudian setelah dilakukan perhitungan koreksi harian (diurnal) dan koreksi IGRF dengan menggunakan mocrosoft excel didapatkan data medan magnet lokal. Setelah melakukan proses gridding, hasil oleh surfer didapatkan kontur sebagai berikut:

Gambar 4.3 Kontur Medan Magnet Lokal Untuk mempermudah pembacaan peta kontur diatas, zona medan magnet total dibagi menjadi 3 bagian, yaitu daerah medan magnet lokal tinggi (diatas $-13.000 \mathrm{nT}$ ), medan magnet lokal sedang (-16.000 - 13.000) dan medan magnet lokal rendah (di bawah -16.000).

\subsection{Kontinuasi ke Atas}

Kontinuasi ke atas atau upward continuation dilakukan terhadap data anomali medan magnet total di bidang datar. Secara umum kontinuasi dilakukan sebagai filter, 
yaitu untuk menghilangkan efek pengaruh medan magnetik total yang bersumber dari benda magnetik yang berada pada permukaan topografi yang tidak terkait pada data.

Kontinuasi ke atas merupakan metode yang sering digunakan untuk menghilangkan noise yang ditimbulkan oleh benda-benda yang dekat dengan permukaan.

Proses kontinuasi ke atas dilakukan dengan aplikasi MagPick dengan memvariasi ketinggian, kemudian membandingkan kontur yang terbentuk menggunakan Surfer 10. Hasil yang diharapkan adalah skala kontur tidak mengalami perubahan ketika ketinggian dirubah. Keluaran yang dihasilkan melalui proses ini adalah berupa data lokal dan regional.

Gambar 4.4 Hasil Kontinuasi ke Atas dengan Elevasi 50, 75 80, 90, 100, 125, 150 dan 175 mdpl

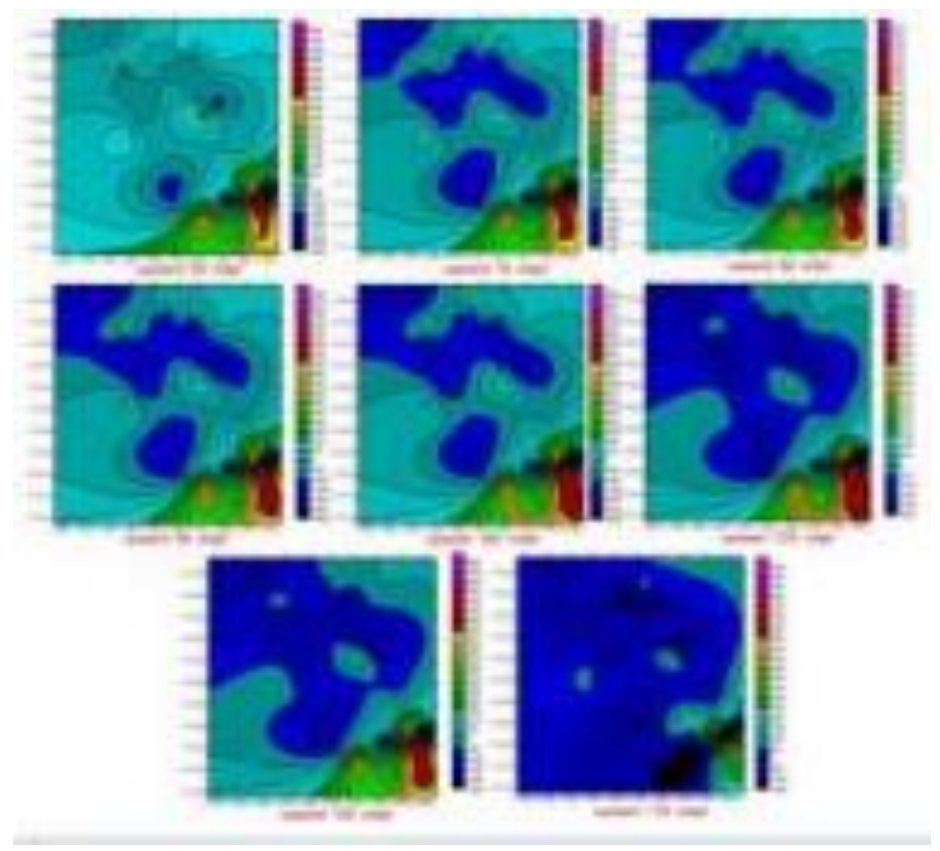

Gambar diatas menunjukkan beberapa kontur hasil kontinuasi ke atas pada elevasi atau ketinggian 50, 75 80, 90, 100, 125, 150 dan 175 mdpl. Angka-angka tersebut dipilih karena lokasi penelitian berada diantara ketinggian 122 - 174 meter diatas permukaan laut.

Dalam interpretasi data magnetik, data dapat diinterpretasikan ke dalam dua cara, yaitu interpretasi secara kualitatif dan interpretasi secara kuantitatif. Interpretasi kualitatif di

dasarkan pada pola kontur anomali medan mag netik yang bersumber dari distribusi benda benda termagnetisasi atau struktur geologi bawah permukaan bumi sedangkan interpretasi kuantitatif dilakukan dengan menganalisa peta kontur medan magnetik lokal dengan hasil yang diperoleh dari lokasi benda penyebab anomali magnetik berdasarkan kontur vertikal (Mag2dc). 


\subsection{Anomali Residu}

Berdasarkan proses kontinuasi ke atas, didapatkan nilai dari variasi elevasi yang kemudian tidak mengalami perubahan kontur adalah pada ketinggian 75 meter - 100 meter. Kemudian diambil salah satu hasil yaitu pada ketinggian 90 meter di atas permukaan laut.

Kontur anomali magnetik residual menggambarkan pola dan karakteristik dari sebaran nilai pengukuran, pelapisan batuan dan struktur yang ada di lapangan dan perhitungan

nilai anomali magnetik residu pada daerah penelitian berkisar antara -700 nT sampai $800 \mathrm{nT}$. Bervariasinya anomali magnetik residu tersebut disebabkan adanya ketidakseragaman material bawah permukaan pada daerah penelitian.

\subsection{Pemodelan Mag2DC}

Interpretasi data dilakukan dengan pemodelan anomali benda dengan menggunakan metode pemodelan benda 2,5 dimensi yang telah dibuat dalam satu paket program Mag2DC. Selanjutnya pola anomali medan magnetik yang dihasilkan ditafsirkan berdasarkan informasi geologi daerah penelitian. Interpretasi bertujuan untuk menentukan bentuk atau odel dan kedalaman benda anomali atau struktur geologi melalui pemodelan matematis. Prinsip kerja Mag2Dc adalah menyamakan bentuk dari anomali pengamatan (garis putus-putus) dengan anomali perhitungan (garis tegas).

Interpretasi data dilakukan berdasarkan hasil penafsiran kualitatif sehingga dapat menentukan bagian-bagian penampang anomali untuk memperkirakan struktur geologi bawah permukaannya. Namun dalam interpretasi data masih belum memiliki kepastian karena beragam model dapat dihasilkan karena adanya parameter suseptibilitas, geometri dan keda laman yang tidak pasti. Sehingga diperlukan data pendukung berupa data geologi daerah penelitian, data bor, data suseptibilitas batuan dan data geofisika lainnya.

Model anomali magnetik residu ada profil garis polyline yang dibuat dengan menggunakan software Surfer 10 kemudian diinterpretasikan dengan software Mag2DC, dimana parameter inputnya adalah sudut inklinasi, sudut deklinasi dan IGRF (medan megnetik utama bumi). Pada daerah penelitian ini harga sudur inklinasi sebesar sudut deklinasi sebesar, dan IGRF daerah penelitian yaitu.

Penampang melintang anomali residua intasan $\mathrm{AB}$ diambil berdasarkan peta anomali hasil penafsiran pola kontur anomali residu yang telah dikorelasikan dengan peta hasil dari reduksi ke kutub. Lintasan $A B$ diambil dari arah barat daya sampai timur laut. 


\section{Gambar 4.5 Penarikan garis polyline pada kontur untuk proses slicing}

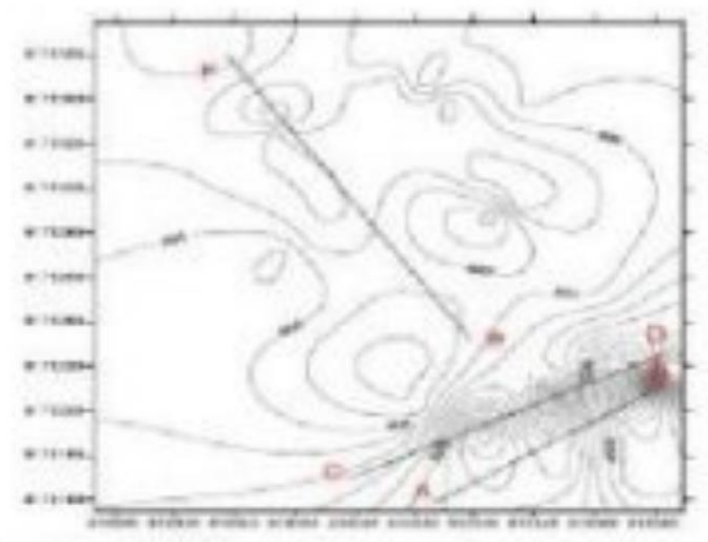

Ditarik 3 (tiga) buah garis polyline pada kontur untuk proses slicing, pada gambar ditunjukkan oleh A-B (lintasan 1) dan C-D (lintasan 2) yaitu di daerah sungai sebagai data primer, dan E-F (lintasan 3) yang berada di dataran atas sungai sebagai data sekunder atau data pembanding dengan data primer.

Hasil dari olah Mag2DC dari lintasan 1 dan lintasan 2 sebagai data primer ditunjukkan pada gambar:

\section{Gambar 4.6 Pemodelan A-B dengan Mag2DC}

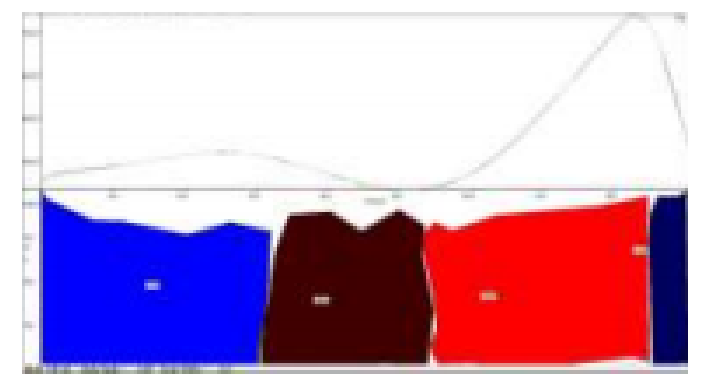

Terdapat 4 body dalam pemodelan medan magnet lokal penampang melintang A-B. Dalam pemodelan ini dapat dilihat bahwa pada daerah yang dimodelkan terdapat 2 jenis batuan yang menyusun permukaan sepanjang lintasan $A-B$, batuan pertama yaitu dengan warna biru muda memiliki suseptibilitas -1,289 dan batuan keempat yang berwarna biru tua dengan nilai suseptibilitas $-0,596$ ditafsirkan sebagai batuan mineral kalsit. Batuan kedua berwarna cokelat dengan suseptibilitas 0,0744 dan batuan ketiga berwarna merah dengan nilai suseptibilitas 0,8921 dapat ditafsirkan sebagai banyak jenis batuan. Namun dengan mempertimbangkan kandungan dari sampel dan bentuk batuan, batuan tersebut diidentifikasi sebagai batuan sedimen. Dengan misfit keseluruhan sebesar 541,06.

Pada lintasan slicing pemodelan A-B batuan yang bernilai negatif $(-)$ adalah batuan pertama dan keempat. Dengan demikian dapat disimpulkan bahwa batuan yang terindikasi mineral kalsit berada pada kedalaman 0 - 10 meter di bawah permukaan tanah dengan posisi pada lintasan pertama. Yaitu berada pada permukaan sungai daerah penelitian. 


\section{Gambar 4.7 Pemodelan C-D dengan Mag2DC}

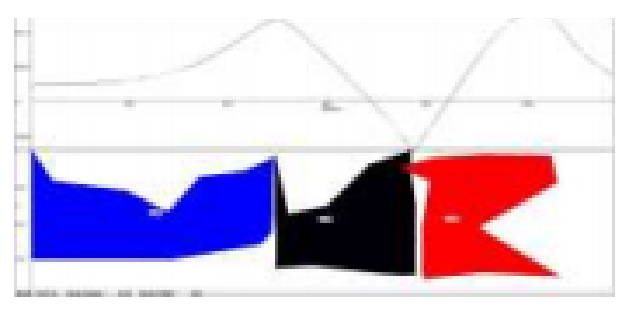

Terdapat 3 body dalam pemodelan medan magnet lokal penampang melintang CD. Dalam pemodelan ini dapat dilihat bahwa pada daerah yang dimodelkan terdapat 2 jenis batuan yang menyusun permukaan sepanjang lintasan C-D, batuan pertama yaitu dengan warna biru, memiliki suseptibilitas $-0,897$ dan batuan kedua dengan warna hitam dengan suseptibilitas - 0,249 ditafsirkan sebagai batuan mineral kalsit. Batuan ketiga dengan warna merah bernilai suseptibilitas 0,425 ditafsirkan sebagai batuan pasir atau batuan mineral lempung. Dengan misfit keseluruhan sebesar 592,35.

Pada lintasan slicing pemodelan C-D batuan yang bernilai negatif (-) adalah batuan pertama dan kedua. Dengan demikian dapat disimpulkan bahwa batuan yang terindikasi mineral kalsit berada pada kedalaman 0 - 8 meter di bawah permukaan tanah dengan posisi pada lintasan kedua. Yaitu berada pada permukaan sungai daerah penelitian.

Sedangkan untuk olah pemodelan Mag2DC pada lintasan ketiga atau sebagai data sekunder ditunjukkan oleh gambar:

Gambar 4.8 Pemodelan E-F dengan Mag2DC

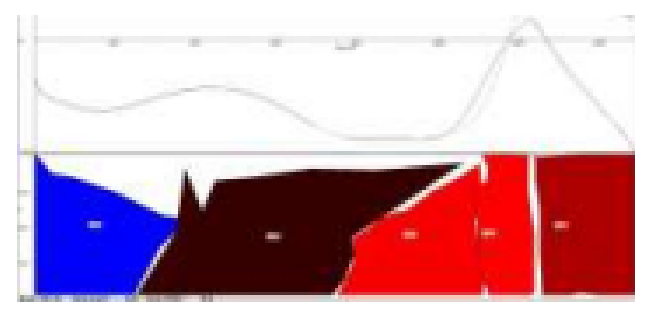

Terdapat 5 body dalam pemodelan medan magnet lokal penampang melintang E-F. Dalam pemodelan ini seluruh jenis batuan merupakan batuan mineral kalsit, namun dengan nilai suseptibilitas yang berbeda. Batuan pertama dengan wara biru memiliki nilai suseptibilitas sebesar $-0,509$, batuan kedua berwarna cokelat dengan suseptibilitas sebesar - 0,204, batuan ketiga dan keemat berwarna merah dengan suseptibilitas sebesar $-0,01$ dan - 0,005, sedangkan batuan kelima dengan warna maroon memiliki suseptibilitas sebesar -0,09. Misfit keseluruhan adaah sebesar 867,85.

Pada lintasan slicing pemodelan E-F dapat disimpulkan bahwa batuan yang terindikasi mineral kalsit berada pada kedalaman 0 - 10 meter di bawah permu-kaan tanah dengan posisi pada lintasan ketiga. Yaitu berada pada permukaan dataran tinggi daerah penelitian. Namun karena pada lokasi lintasan ketiga berbeda dengan lintasan pertama dan kedua, yaitu berda di dataran tinggi pinggiran sungai dan memiliki 
permukaan berupa tanah, dapat disimpulkan bahwa di bawah permukaan tanah tersebut juga terdapat mineral kalsit.

Ketidakberaturan gambaran bentuk batuan secara permukaan dikarenakan kecilnya nilai suseptibilitas dari batuan mineral kalsit, yaitu bernilai negatif. Sedangkan besarnya misfit atau tingkat kesalahan yang terjadi dikarenakan adanya radiasi langsung dengan sinar ultraviolet di alam sehingga memperbesar noise ketika pengambilan data, tingginya tingkat error dari alat (magnetometer) yang digunakan, titik pengambilan data yang tidak beraturan sehingga menyebabkan nilai medan magnet total yang terdeteksi menghasilkan kontur yang kurang sesuai.

\section{Simpulan}

\subsection{Kesimpulan}

Berdasarkan hasil analisis data dan pembahasan yang telah dilakukan di kawasan Grojokan Dhuwur Desa Sumbermiri Kecamtan Lengkong Kabupaten Nganjuk dengan menggunakan metode geomagnet, dapat disimpulkan bahwa di area tersebut ditemukan batuan yang mengandung mineral kalsit dengan nilai medan magnet lokal $-3.000-8.000 \mathrm{nT}$ pada kedalaman 0 - 10 meter di bawah permukaan sungai pada titik lokasi penelitian.

\subsection{Saran}

4.2.1. Lebih memperhatikan tipe magnetometer yang akan digunakan. Karena noise yang timbul juga dipengaruhi oleh alat.

4.2.2.Perlu dilakukan pengukuran di kawasan yang sama, namun pada titik yang berbeda untuk melihat potensi mineral kalsit di sekitarnya.

4.2.3.Perlu dilakukan penelitian atau analisis lebih lanjut mengenai sejarah pembentukan batuan dan kedalaman batuan dengan menggunakan metode yang berbeda.

\section{Daftar Rujukan}

Alam, Cimby Wicaksono Rezeki Nur. (2014). Aplikasi metode geomagnetik untuk identifikasi persebaran batuan beku dasit di Gunung Siwareng Kabupaten Sleman Daerah Istimewa Yogyakarta. PROCEEDING 1st International Conference of Energy and 7th Indonesia - Malaysia Geoheritage Conference

Anwar, U. H. (2009). Analisis potensi panas bumi di daerah Cangar Ds. Sumber Brantas, Kec. Bumi Aji, Kab. Malang, Prop. Jawa Timur dengan menggunakan metode geolistrik (Doctoral dissertation, Universitas Negeri Malang).

Bomba, B. B. (2012). Pemetaan distribusi pada permukaan bumi satu titik sumber panas di Cangar Sumber Brantas, Kec, Bumi Aji, Kab, Malang Prop, Jawa Timur (Doctoral dissertation, Universitas Negeri Malang).

Cowan, R. T., Robinson, J. J., McHattie, I., \& Pennie, K. (1981). Effects of protein concentration in the diet on milk yield, change in body composition and the efficiency of utilization of body tissue for milk production in ewes. Animal Science, 33(2), 111-120.

Doddy, S. G. (1987). Batuan dan Mineral. Penerbit Nova Bandung.

Engineering ToolBox (2014, Nopember 24). Latitude and Longitude Converter . https://www.engineeringtoolbox.com/latitude-longitude-d_1371.html

Fernania, N., Maryanto, S., \& Rakhmanto, F. (2013). Identifikasi Litologi Daerah Panasbumi Tiris Probolinggo Berdasarkan Metode Magnetik (Doctoral dissertation, Brawijaya University). 
Kurniasari, W. (2014). Identifikasi litologi bawah permukaan Gunung Welirang dengan menggunakan metode gaya berat (Doctoral dissertation, Universitas Negeri Malang).

Morton, Alan. (2005, Nopember 24). UTM Grid Zones of the World Compiled. http://www.dmap.co.uk/utmworld.htm

Nurdiyanto, Boko and Wahyudi, Wahyudi and Suyanto, Imam (2004). Analisis data magnetik untuk mengetahui struktur bawah permukaan daerah manifestasi air panas di lereng utara gunungapi ungaran. Prosiding PIT ke 29 HAGI 2004

OJO, A. O., \& POPOOLA, O. (2014). Geomagnetic investigation of mineral rocks at Awo, Osun state, southwest Nigeria.

Perdana, O. A. (2014). Aplikasi metode geomagnet untuk mengidentifikasi mineral kromit di desa Sukorejo kecamatan Kalidawir Kabupaten Tulungagung. skripsi jurusan fisika-fakultas MIPA UM.

Romdhon, S. (2013). Pemetaan potensi geothermal di daerah candi Songgoriti dengan menggunakan metode geomagnet (Doctoral dissertation, Universitas Negeri Malang).

Sehah, S. A. (2013). Raharjo, dan A. Chandra, Aplikasi metode magnetik untuk men-gidentifikasi struktur lapisan bawah permukaan sungai Logawa, desa Kediri, kecamatan Karanglewas, kabupaten Banyumas.. Jurnal Geofisika, 14(01), 121-130.

Telford, W. M., Telford, W. M., Geldart, L. P., \& Sheriff, R. E. (1990). Applied geophysics. Cambridge university press.

Widodo, Wahyu (2010, Maret 24). UTM/TM3 projection system for Indonesia. http://rwwidodo.blogspot.com/2010/03/utmtm3-projection-system-for-indonesia.html

Wulandari, J. C. (2014). Identifikasi struktur litologi daerah panas bumi Probolinggo menggunakan metode magnetotelurik (MT) (Doctoral dissertation, Universitas Negeri Malang). 